\title{
Analysis of The Influence of Strategic Leadership in Increasing Financial Performance
}

\author{
Puspita Putri Kirana \\ Soegijapranata Catholic University \\ puti.poe@gmail.com
}

\begin{abstract}
This research was to analyze the influence of strategic leadership in increasing financial performance in CV SB, an entertainment company in Semarang. Here, strategic leadership was measured using four indicators as in Lumpkin and Dess (1996), namely promotion, mentoring, discipline, and cooperation. This research used qualitative descriptive to describe and picturize situations of the object based on facts. Observation on operations of the company, interview to the manager and several employees, as well as documentation were to collect data. Triangulation was to validate the data in which data reduction, data presentation, and conclusion were the process in analysis. The result shows that the four indicators of leadership have run well and they influenced the promotion and human resource programs of the company that in turn positively affect financial performance. More specifically, promotion and mentoring influenced promotion program, while discipline and cooperation influenced human resource program.
\end{abstract}

Keywords: cooperation, discipline, financial performance, mentoring, promotion, strategic leadership

\section{INTRODUCTION}

A company has goals it wants to achieve during its existence. Achievement of the goals indicates performance of the management and financial performance of the company can reflect it. Financial performance summarised in a financial report reflects company condition in a particular periode of time and management performance. Thus, analysing financial performance is important for not only indicating company's conditions but also fulfilling obligation to the investors. Financial performance can thus be the basis for making managerial decision.

Leadership is an important factor for the success of an organization in especially for achieving its goals becuase a leader is responsible for the success and failure in performning a job. Considering the dynamic and challenging external conditions, a leader must thus have 
good credibility and reputation so they can inspire people under their responsibility and in their surrounding and direct the company to positive changes. A leader must also motivate their subordinates to be able to adapt to the changes and work harder in achieving the plans.

CV SB is an entertainment company in Semarang offering executive karaoke. It brings oriental themes targeted to middle up class consumers. It is a unit business of a corporation led by an outlet manager. The top management gives full delegation to the outlet manager to make all the decisions in the unit business. The outlet manager only needs to report to the top management their outlet performance including financial report every three months. The top management will evaluate the outlet performance in terms of revenue and gross operational profit/loss.

CV SB has been experiencing revenue decline since the beginning of 2007 and thus it is under evaluation of the top management. The research aims to analyze the role of strategic leadersip in increasing financial performance in CV SB Semarang.

\section{LITERATURE REVIEW}

According to Lumpkin and Dess (1996), strategic leadership is an ability to anticipate, to have mission, to maintain flexibiliyt, and to delegate to others to create necessity strategic changes. Strategic leadership is multifunction as it involves management through others and helps organization to face rapid changes in the competitive environment.

An effective strategic leader must adapt his(her) framework in such a way that enables him(her) to handle rapid and unexpected changes in this global environment. He(she) must be able and want to make right and difficult decisions that pragmatically can overcome internal and external conditions his(her) company is facing.

Lumpkin dan Dess (1996) stated that strategic leadership includes four indicators, namely orientate on promotion, give leadership, be on time, and prioritize cooperation. It is 
crucial for an organisation since the management that can lead effectively can bring the organization to achieve its main goals and keep focus on the competitive business environment. Thus, an organization needs a leader with strategic and visionary way of thinking and behavior in order to be able to make effective decisions.

Cobbold (2004) concluded that important contribution of strategic leadership is to determins goals, values, and system that can lead to the sustaiable work improvement. A great leader must thus develop them continuously, gives beneficial inspiration dan leads employee properly to achieve their goals.

Hitt (1998) wrote about abilities for effective strategic leardership in the new competitive landscape in the 21st century. He stated that an effective strategic leader must develop and communicate a vision, creates dynamic core competence, emphasizes and uses human capital effectively, invests in new technology development, involves in valuable strategy, develops and maintains effective organizational culture, develops and implements balanced control, and involves in ethical practices.

In strategic leadership, top manager is an important asset for the company. Thus, the most important component of an organization is to have top management with better managerial ability. Hitt (1995) noted components a top management must have. They must have vision, business knowledge, relations, ability to coordinate top management team, ability to make better changes, special skills, leadership ability, relationship with key persons, and general managerial ability.

Hertawan (2015) found that strategic leadership and business environment indirectly influence business performance through business performance. This indirect influence is higher than the direct influence. Furthermore, Akil’s study (2014) concluded that strategic leadership can be implemented in every business strategy level. 
This research aims to see strategic leadership from the four indicators (promotion, mentoring, discipline, and cooperation) in relations to functional management program and its effect on financial program. The research framework is as follows:

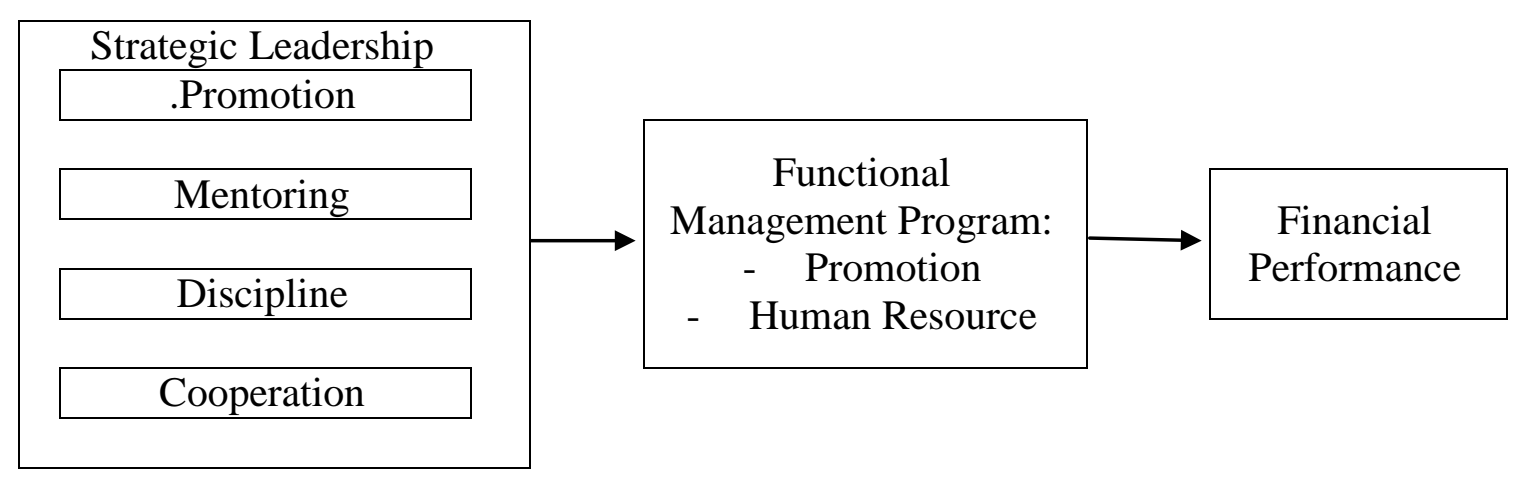

Figure 1. Research Framework

\section{METODOLOGY}

This research applied qualitative descriptive method in which it describes and picturizes current conditions of the object based on facts (Moleong, 2008: 6). The object was an operational outlet of CV SB in Semarang.

The research used primary data that were collected directly from the source (Afifuddin and Saebeni, 2009: 117) and secondary data gathered from the outlet's documents.

Interview was to collect the primary data. Interview was with the outlet manager who has full responsibility for the operations of the company. The interview was based on a questionnaire comprising the indicators of strategic leadership. Interview with some employees was to explore their opinion on the leadership of the outlet manager and decisions applied in the company.

The secondary data used in this research comprise of the company's financial statement, organization structure, and job description of the divisions, number of consumers attending the outlet during October 2017 - April 2018, employees late arrival in the periode 
of October 2017- April 2018, and profit/loss statement in the periode of October 2017 April 2018.

The researcher applied a non-participant observation in which the researcher did not position herself as part of the members observed. It was conducted by attending daily briefings and observing activities available in the outlet.

These three methods were to validate date using data triangulation. It is a technique to check validity of data using other data as the comparison (Moleong, 2005). Data from each source were collected at different time and then were compared to see if consistency exists. The data is valid if consistency exists.

The researcher summarized data gathered from interviews, observation, and documents in order to reduce the data. The researcher described the findings from the interviews and supported them with the secondary data presented in either tables or figures. They were intended to know the financial performance of the outlet using revenue and gross operational profit in the periode of October 2017 - April 2018. Based on the descriptive analysis on the data, conslusions withdrawn were to answer the research problem.

\section{RESULTS AND DISCUSSION}

\section{Company Profile}

CV SB is a service company offering executive karaoke with song leaders available in need. It also offers alchoholic beverages as it is an authorized registered seller under the Surat Ijin Usaha Perdagangan Minuman Beralkohol (SIUP-MB). It targets middle up class consumers and offers uniqueness as a themed karaoke. Its theme is oriental and specific theme is changed everuday according to the demand of the customers. Currently, the company combines the oriental with other themes without losing its uniquness as the oriental karaoke. 
It employs 30 people comprising 1 Outlet Manager, 1 Chief Accountant, 2 SPV Operasional staffs, 1 Marketing staff, 1 Accountant, 1 Purchasing staff, 1 Cost Controler, 1 Storeman, 1 HRD staff, 3 mecanics, 1 IT staff, 4 Servers, 3 Bartenders, 3 Receptionists, 4 Security officers, and 2 talent coordinators. The outlet manager has full responsibility to make decisions and strategic actions for operational the company. He reports to the top management every three months for any decisions and actions to reach targeted revenue and Gross Operational Profit/Loss. The top management uses these to evaluate financial performance of the company.

\section{Findings}

Below is the description on each indicator of strategic leadership covering promotion, mentoring, discipline, and cooperation.

\section{$\underline{\text { Promotion }}$}

In term of promotion, the company used social media such as facebook, twitter, instagram, and short message via whatsapp and blackberry messenger to promote the service. The manager involved all employees in all divisions in promoting via whatsapp and blackberry messenger for expanding the coverage.

The company cooperated with some online medias to get space for its promotions. It evaluated the promotions by conducting short cut interview with consumers to get feedback and to know the extent of brand awareness based on the number of consumers coming to the outlet due to the promotion.

The company created events with specific theme each month. What differentiates monthly theme from daily theme is the detail of the concept. In daily theme, the decoration, the employees' customs, and live band were in accordance to the theme. In monthly theme, the company offered games or lottery for every customer who come and gave gifts such as free room voucher dan free bottle. 
Conforming these promotions to the employees, it is apparently so that the employees were involved in promoting the thematic events through especially social media shot messages application since they possibly have the applications and personal social media. The marketing department managed the company social media. This way created active participation from the employees. They considered that the promotions decided by the manager had been effective and were able to increase revenue in the periode of October 2017

- April 2018.

\section{Mentoring}

The manager defined mentoring as a communication way that could direct the employees to do their tasks according to their responsibility and found the best solutions for obstacles faced in opearting the business. The manager chose open and flexible communication way with his employees. He positioned himself as an open person with whom employees could communicate about jobs or pesonal matters that hinder them to do their jobs well.

The manager built emotional closeness with the employees to make them comfortable. Such internal communication has been implementing as it was considerably important and could affect external communication with suppliers and people.

The manager became the mentor by directing employees who has potencies to attend the Training Center. He also gave mentoring to the employees by giving managerial direction on how to do the opration of the company and discussing about solutions on problems the company has ever had.

The manager conducted daily briefing for employees from all divions before starting the operation. He directed all divisions to be responsible to each jobs, found alternative solutions for problems in each division, and motivated them to give the best service. According to the employees, the manager had conducted good mentoring and they 
understood it well.

\section{Discpline}

The manager asked the employees to come for working on time as their discipline. A rule stated in Standart Operational Procedure was made and applied to all employees. Personel staff counted absences each month. The manager gave good example by come for working on time and the employees confirmed this.

The manager was satisfied with the discipline since the number of indiscipline employees was decreasing and this related to the reward and punishment applied by the company. However, the employees disconfirmed this as they witnessed that many still came late.

\section{Cooperation}

Intenal cooperation was emphasized since the manager thought that a good teamwork generates good output. It was in the form of communication for executing daily operations and monthly thematic events. Here, the employees communicated each other during preparation, execution, and evaluation of an event from which strengths and weaknesses of an event could be the lessons for conducting better events in the future.

According to the manager, a good teamwork is when operation division, marketing division, and accounting division cooperate in a way that marketig division could sell the concept well, operation division could execute properly, and accounting division could control finance correctly. This way could then affect positively on profit.

\section{$\underline{\text { Strategic leadership in Functional Management Program }}$}

As stated by Lumpkin and Dess (1996) that the four indicators of strategic leadership influence functional program in promotion and human resource. The result shows that strategic leadership in promotion and mentoring influenced functional program of promotion and dicipline and cooperation influenced functional program of human resource. 
The decisions on promotion related to the choice of media and concept offered by the company. Meanwhile, mentoring was particularly addressed to marketing division and all employees in relation to the promotions that were or would be run. The manager reminded the employees about the importance to participate in all promotions the company launced.

In relation to the functional program of human resource, it can be seen that the discipline reflected in the decisions made by the manager influenced the employees' attendance each month. Meanwhile, the cooperation was implemented on coordination between the manager and the employees and between the employees in executing the operation in the company.

\section{Financial Performance}

The manager has to present financial statement periodically every three months to the top management who specifically evaluate the performance based on revenue and gross operational profit/loss (GOP). During the periode of October 2017 - April 2018, it can be seen that revenue and GOP were increasing (figure 1).
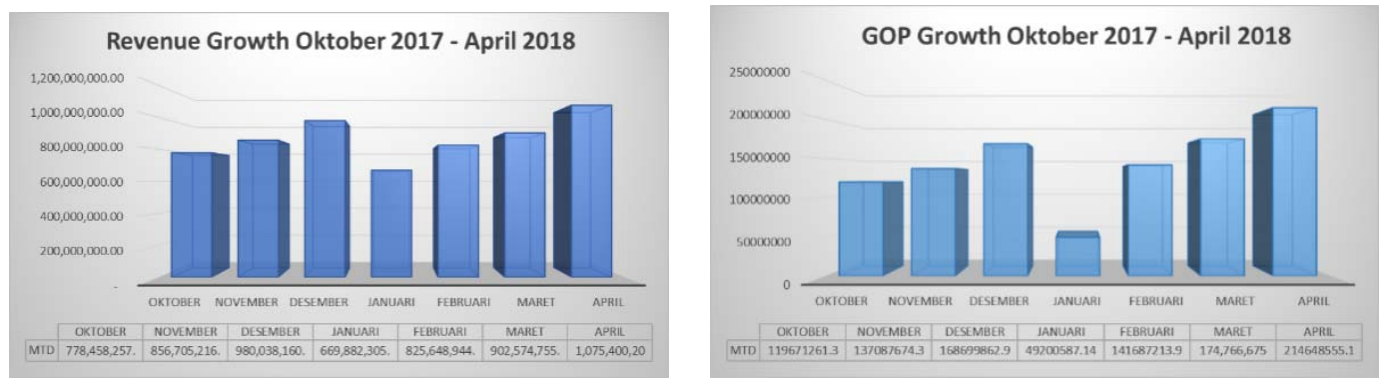

Figure 1. Financial Performance

\section{CONCLUSSION}

As the leader, the manager was able to think strategically in deciding on effective promotion for the company. He decided to use popular social media for promotion and for finding current trends. Then, marketing division conducted short cut interview to get feedback directly from the customers. The feedback was very beneficial for the company.

In term of mentoring, the manager conducted mentoring in several ways. Personally, 
he was open to all employees and could direct them to do their jobs responsibly. He also could give alternative solutions for any obstacles experienced by the employees or the company. Formally, the mentoring was applied in the Training Center run once a year.

The manager used Standard Operational Procedure (SOP) as the basis in giving understanding to the employees and in making decisions. Recognition was given as one form of reward and punishment. It was to motivate employees to be more discipline.

In term of cooperation, the manager focused on cooperation between employees and barriers to do it. Uch focus was considerably important in generating good communication for executing daily operation in the company.

These four indicators of strategic leadership had run well and influenced functional program of promotion and human resource. More specifically, promotion and mentoring affected functional program of promotion through decisions made by the manager that would then be executed by marketing division. Mentoring to all employees had been implemented well and this impacted the operation division to serving customers well. Discipline and cooperation influenced functional program of human resource. Even though cooperation between the manager and employees and among employees had run well, but controling employees discipline is needed as the empolyee late is still quite high. Generally, the four indicators had run well and they influeced positively financial performance of the company.

\section{REFERENCES}

Akil, Nashriah. 2016. Model Penerapan Kepemimpinan Strategis Untuk Menciptakan Keunggulan Bersaing Pada Bengkel Perawatan Dan Perbaikan Toyota PT. Hadji Kalla Cabang Urip Sumoharjo Makassar. Jurnal Bisnis dan Kewirausahaan. Vol 5 No 2. Diakses dari :https://e-jurnal.stienobel-indonesia.ac.id/index.php/jibk/article/view/48

Arisbah, Muklis, Maria Magdalena Minarsih dan Azis Fathoni. 2018. Pengaruh Strategic Leadership Dan Keefektifan Pemimpin Berkompeten Dalam Membangun Sumber Daya Manusia Terhadap Kinerja Karyawan PT Dong Bang Indo (Studi Kasus pada PT Dong Bang Indo Kabupaten Semarang).Journal Of Management. ISSN:2502-7689. Diakses dari 
:http://jurnal.unpand.ac.id/index.php/MS/article/view/1111/1086.

Baihaqi, Muhammad Arif. 2011. Analisis Peran Kepemimpinan Strategis Dalam Membangun Kapabilitas Inovasi Di PT. Garuda Indonesia. Tesis. Universitas Gajah Mada: Yogyakarta. Diakses dari: http://etd.repository.ugm.ac.id/index.php?act=view\&buku_id=51111\&mod=penelitian_detai I\&sub=PenelitianDetail\&typ $=h t m l$.

Hartono, Chriselda Yolanda. 2017. Analisa Gaya Kepemimpinan Direktur Utama Di PT. Bukit Mustika Persada. AGORA. 5(1). Diakses dari: http://publication.petra.ac.id/index.php/manajemen-bisnis/article/view/5186.

Hernowo, KenditilaCromaviant. 2016. Pengaruh Kepemimpinan terhadap Employee Engagement PT Astra International Tbk. Tesis. Universitas Gajah Mada : Yogyakarta. Diakses dari: http://etd.repository.ugm.ac.id/index.php?act=view\&buku_id=106387\&mod=penelitian_det ail\&sub=PenelitianDetail\&typ $=h t m l$.

Hertawan, Yudi. 2012. Pengaruh Lingkungan Bisnis dan Kepemimpinan Stratejik Terhadap Strategi Bersaing dan Kinerja Bisnis (Studi pada Hotel Non Bintang di Provinsi Kepulauan Riau). Disertasi. Universitas Padjajaran: Bandung. Diakses dari :http://journal.feb.unpad.ac.id/index.php/jbm/article/download/13/18

Hitt, Michael A. 2010. Strategic Leadership for the 21st Century. Business Horizons.53:437444. Diakses dari: https://www.researchgate.net/publication/227413590_Strategic_leadership_for_the_21_cent ury.

Ikatan Akuntan Indonesia, 2008, Standar Akuntansi Keuangan (SAK), Jakarta: Salemba Empat, 2008.

Miftah, Toha. Kepemimpinan Dalam Manajemen, Jakarta: CV Rajawali, 1988.

Prasetio, Arif Partono. 2014. Kajian Teori Kepemimpinan Strategik. Universitas Pendidikan Indonesia: Bandung. Diakses dari: http://www.academia.edu/11697325/Kajian_Teori_Kepemimpinan_Strategik.

Son, Wandrial. 2011. Strategic Management Dan Strategic Leadership: Dua Sisi Mata Uang Kemampuan Untuk Hadapi Tantangan Perubahan Lingkungan Yang Drastis. Binus Business Review. 2(1):415-422. Diakses dari: http://eprints.binus.ac.id/13610/.

Supartha, I Wayan. 2011. Analisis Pengaruh Kepemimpinan Stratejik, Dan Karakteristik UMKM Terhadap Strategi Bisnis Dalam Meningkatkan Kinerja UMKM Nasabah PT. Bank BRI, Tbk Kanca Purwodadi. Jurnal Bisnis Strategi. 20(2):64-86. Diakses dari: https://ejournal.undip.ac.id/index.php/jbs/article/viewFile/14355/10944.

Trisnawati, Imas. 2012. Analisis Kemampuan Pemecahan Masalah Multistep Pada Materi Soal Cerita Perbandingan dan Skala Siswa Kelas V Sekolah Dasar. Universitas Pendidikan Indonesia. Diakses dari: http://repository.upi.edu/9397/3/t_pd_1007364_chapter3.pdf. 